\title{
Article \\ Analyzing Residents' Landscape Preferences after Changes of Landscape Characteristics: A Qualitative Perspective
}

\author{
Fuer Ning ${ }^{1,2}$ and Sheng-Jung $\mathrm{Ou}{ }^{1, *}$ \\ 1 College of Design, Chaoyang University of Technology, Taichung 413, Taiwan; s10812905@gm.cyut.edu.tw \\ 2 College of Art and Design, Dalian Art College, Dalian 116600, China \\ * Correspondence: sjou@cyut.edu.tw; Tel.: +886-4-23323000-7601
}

Citation: Ning, F.; Ou, S.-J. Analyzing Residents' Landscape

Preferences after Changes of Landscape Characteristics: A Qualitative Perspective. Land 2021, 10, 1128. https://doi.org/10.3390/ land 10111128

Academic Editor:

Ileana Pătru-Stupariu

Received: 17 September 2021

Accepted: 19 October 2021

Published: 24 October 2021

Publisher's Note: MDPI stays neutral with regard to jurisdictional claims in published maps and institutional affiliations.

Copyright: (C) 2021 by the authors. Licensee MDPI, Basel, Switzerland. This article is an open access article distributed under the terms and conditions of the Creative Commons Attribution (CC BY) license (https:/ / creativecommons.org/licenses/by/ $4.0 /)$.

\begin{abstract}
China is one of the world's fastest-growing countries, and the scale of its cities continues to expand, causing tremendous changes to the ecological environment. The purpose of this research is to improve urban fringe future planning from the perspective of landscape preference. This study takes the area of Shenyang City as an example and selects six locations with high consensus on the tested areas. We used the narrative interview method for the landscape paradigm, combined with spatial quantification, government policies, and major events, to conduct a comprehensive analysis and summarize past environmental appearance. A content analysis method was also used to summarize the landscape features that residents prefer after 15 years of environmental changes, including three types and ten dimensions. From the perspective of landscape preference, a plan for urban fringe areas is proposed.
\end{abstract}

Keywords: urban fringe; landscape change; experiential paradigm; landscape preference

\section{Introduction}

The world is undergoing urbanization. By 2050, about $70 \%$ of the world's population will probably live in urban areas [1]. This is also true for China, one of the fastest-growing countries in the world. The scale of Chinese cities continues to grow and expand, and they are undergoing tremendous change. Decision-making concerning land by natural resource managers and urban planners may be more critical than ever, especially in urban fringe areas where there is tremendous pressure from rapid growth. In the past 30 years, Shenyang's urbanization and industrialization have developed rapidly. The intensity and pattern of land use has undergone tremendous changes, and the landscape environment has undergone profound changes [2-4]. The urban fringe landscape has changed with time, and rapid urbanization has caused significant changes to the ecological environment. Original farmland and forestland are gradually disappearing, replaced by scenic spots and living spaces. Therefore, what kind of environmental perception do such changes to the landscape environment bring to residents? Can they recall what the landscape looked like 15 years ago? Do they prefer the present landscape environment or prefer the past? Why? In fact, the discussion of these issues is closely related to the future development of land, and it is worthy of in-depth study.

The landscape as a living environment is very important to people's well-being $[5,6]$. With dramatic changes to the landscape, understanding how people treat the landscape is essential for decision making and planning [7]. The landscape is a synthesis of ecological, social and visual qualities [8]. Ho (2009) [9] believes that natural, cultural, and social factors should be included in landscape discussions to form a "cultural landscape" that combines human beings and nature. Therefore, the landscape includes not only the physical "scene" but also the inner " perception " of the viewer. The landscape is conceptually integrated and complex [10]. In summary, due to differences in life experience and background, people tend to focus on their interests and produce different cognitions and imaginations when viewing the same landscape. 
In landscape research and land management, residents' evaluation or assessment of the landscape environment is increasingly important to improve local policy-making [11-13]. Changes to the physical environment of a landscape greatly affect residents' perception preferences of the visual and sensory landscape [14]. The Swiss Landscape Monitoring program (LABES) is a landscape monitoring program. This program includes evaluating natural landscape indicators and includes public perception evaluation [15]. However, Chinese researchers and policymakers have not given enough attention to residents' attitudes towards landscape changes, but the preferences and attitudes of residents are vital in landscape management $[16,17]$.

Landscape assessment is the research focus of landscape aesthetics. It is of great guiding significance for landscape protection, resource management, and planning [18]. Landscape assessment is divided into four significant paradigms: expert paradigm, psychophysical paradigm, cognitive paradigm, and experiential paradigm [19]. Expert paradigm is a method in which experts with professional technical backgrounds transform the physical characteristics of a landscape into the formal aesthetics of a landscape as the basis for evaluation. However, this method has been questioned due to insufficient accuracy, reliability, and effectiveness. The psychophysical paradigm includes SBE (scenic beauty estimation) and LCJ (law of comparative judgement) which treat the physical characteristics of the landscape as stimuli. The cognition paradigm aims to arouse people's psychological responses by intervening in the cognitive structure. The experiential paradigm focuses more on the meaning of landscape aesthetics beyond the visual dimension to human beings and believes that human beings are participants in the landscape and obtain their values from experience $[20,21]$. Seamon (1982) [22] clearly pointed out that only through the experiential paradigm can the most fundamental human attitudes towards the landscape be fully revealed. Therefore, the experiential paradigm can obtain human evaluations of the visual dimension of the landscape and acquire the meaning of the landscape to humans from the psychological dimension and the experience and shaping of the landscape by humans [22]. The experiential paradigm research method is generally carried out to verify the background of literary artists' judgments on the aesthetics of the landscape and through psychological measurements, investigations, and interviews. The experiential paradigm describes the perceptions and assessments of modern people on the landscape and describes the interviewee's personal experience and feelings about a certain landscape [23]. Presently, relevant studies have explored the experiential paradigm. For example, Loder (2014) [24] explored the views of office workers on roof greening, Chen (2012) [23] applied the experiential paradigm to explore the landscape experience of bloggers in Sun Moon Lake, whereas Davenport and Anderson (2005) [12] discussed the attitudes of residents on the landscape changes of local rivers. Throughout the existing studies, most researchers adopted psychophysical and cognitive paradigms to evaluate the landscape. However, it is rare in Chinese academic circles to utilize the empirical paradigm of an interview to explore residents' preferences in the context of environmental changes, so the current study can make up for the gap in this area.

The survey interview method is not only a method of experience paradigm but also a form of expression of landscape narrative [25]. The landscape narrative method is suitable for investigating residents [26]. The conceptual landscape narrative is closely related to a location's identity, and the narrative and story reflect personal memories and feelings of identity [27]. Incorporating landscape narrative into landscape assessment can record and capture people's past, present, and future stories of the area and landscape changes [26]. The landscape narrative is included in the present research. Verbrugge and van den Born (2018) [26] incorporated landscape narratives into place attachment and constructed aesthetic interventions on Dutch rivers from a public perspective. Kao and Li (2017) [28] constructed a landscape experience model in tourist destinations with landscape narrative interviews. Soliva and Hunziker (2009) [29] used landscape narrative descriptive results to formulate future landscape scenarios, thereby analyzing people's assessment of landscape 
plans. It is necessary to use the experience paradigm of landscape narrative interviews to study landscape preference.

In landscape research, the exploration of landscape preferences has a long history [30]. Appleton (1996) [31] put forward the prospect/refuge theory, which postulates that humans prefer to be within the scope of the field of view to appreciate beautiful scenery. Wilson (1984) [32] proposed biophilia, and believed that humans prefer natural landscape environments and biodiversity habitats. The theory of landscape preference under the model of landscape perception was constructed by Kaplan and Kaplan (1989) [33]. They pointed out that there are four factors summarized in the landscape preference matrix that affect landscape preferences: coherence, legibility, complexity, and mystery. If these four factors are present in natural and architectural landscapes, this represents a preferred environment. After the millennium, Tveit et al. (2006) [34] summarized nine key visual landscape conceptual frameworks and attempted to establish an objective measurement system. The nine key concepts are stewardship, coherence, disturbance, historicity, visual scale, imageability, complexity, naturalness, and ephemera. Hunter and Askarinejad (2015) [35] integrated landscape-related theories and constructed a conceptual model based on the extraction of image features. This model contains ten facets: naturalness, structure coherence, structural form, depth cues, openness, and information gathering support, accessibility, safety, and engagement. Landscape preferences change over time [36] and research into these preferences should be persistent.

At present, research on the development of urban fringe areas has several aspects. For example, the pattern and driving force of land use [2,37], ecological security and food security [38], and environmental interactions [39] involves models to simulate and monitor the development of fringe areas [40,41]. Ning et al. (2021) [2] obtained the status and driving factors of land use from the perspective of landscape spatial patterns and proposed the "rational expansion" development of urban fringe areas. Xia et al. (2021) [38] quantified the dynamics of green infrastructure (GI) in agriculture and conducted a spatio-temporal dynamic assessment. Their study found that ensuring the dominant position of farmland in urban fringe areas is crucial to maintaining overall composition and connectivity. Goodarzi et al. (2020) [39] advocated improving the structure and function of urban fringe areas by considering socio-economic factors and ecological principles to achieve sustainable interaction between buildings and the natural environment. Wang et al. (2021) [40] developed a spatial segmentation model (SSM) to understand the extent of the urban fringe area to understand its dynamics and lay the foundation for future development. Throughout research in recent years, there has been marginal literature on the development of urban fringe areas from the perspective of landscape preference.

In summary, in China, the urban fringe area is a rapidly developing area that has been given less attention. Historical maps, documentary records, and image data are not comprehensive and detailed enough. Therefore, from the experiential paradigm perspective, the current research involved interviewing residents to fully excavate their landscape narrative samples and memories using qualitative research and uses content analysis methods with Nvivo 12 software to: (1) explore the past landscape appearance of the study area and supplement the lack of image data; (2) interpret residents' landscape preferences for the past environment and the present environment, analyze the reasons for their preference, and make a summary and induction and (3) provide reference suggestions for the development and planning of urban fringe areas. This study aims to support landscape management by understanding residents' preferences for landscape changes.

\section{Methods}

The study, which explores the research area based on the experiential paradigm, used a qualitative research method. First, interviewees were asked to look at six photos, were asked if they could recognise the specific location, and then were given a semistructured interview. The interview adopted a convenient sampling method, then the interview content was converted into verbatim text, content analysis was used for analysis, and 
the text was encoded using Nvivo 12 software. In addition, this research also combined comprehensive methods such as spatial quantitative analysis to gather information about the process of land use change, change of the environment, and other value changes.

\subsection{Study Site}

As the scale of the landscape is relatively large, it was necessary to start from a point of view that could be grasped. The exploration of selecting representative places is a specific and meaningful approach.

The study area is located in Hunnan District, Shenyang City, Liaoning Province, China (Figure 1a-d). The study selected six familiar and regional landmark locations in the study area from which to take photos of the physical landscape (photographed on October 3, 2020) (Figure 1e). The selection of these six locations was obtained through a survey in advance.

Viewpoint 1 is called the water area by the Hun River (Figure 1(e1)). Viewpoint 2 is called the cultural heritage (Figure 1(e2)), where the world's cultural heritage Qingfu Mausoleum is located, and its location covers a large area of forest. Viewpoint 3 is called the residential area (Figure 1(e3)), which was mainly bare land but is now a residential area mainly for construction land. Viewpoint 4 is called the scenic area (Figure 1(e4)) where the land in the past was a mixture of construction land, cultivated land and grassland and is now the parking area for the national 5A-level tourist attraction "World Horticultural Expo Park." Viewpoint 5 is called business area (Figure 1(e5)) where the land in the past was used for construction land and has remained unchanged. Viewpoint 6 has always been cultivated land, and this viewpoint is called cultivated land (Figure 1(e6)).
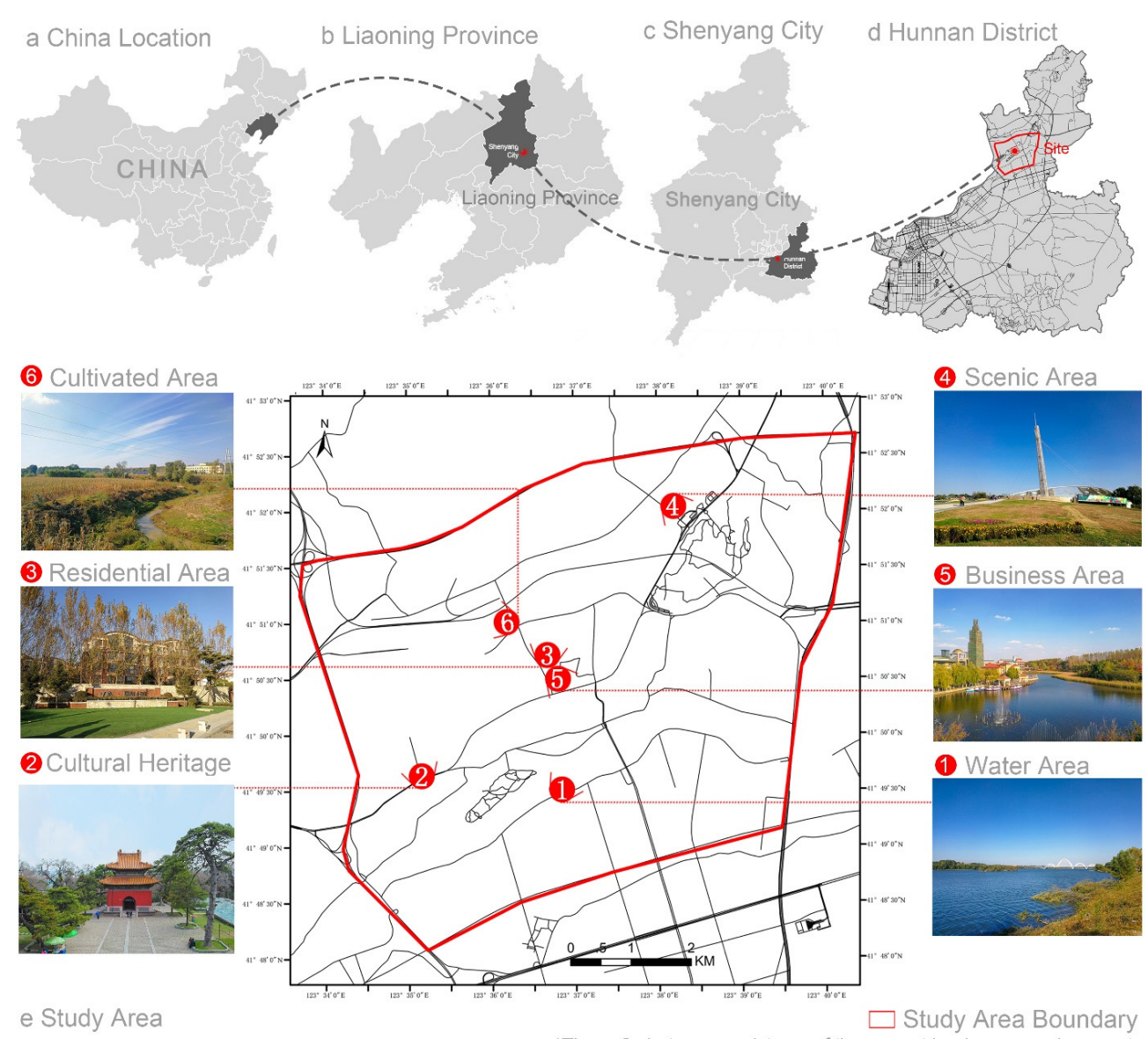

Figure 1. Location of the study area. 


\subsection{Data Collection Source}

Data collection for this study was divided into three parts. The first was the landscape narrative interview of the experience paradigm. Respondents were selected according to theoretical sampling strategy. Respondents provided different attitudes and opinions on the past and present environment. Theoretical sampling is not numerically representative but covers a wide range of opinions and values (see Figure 2 in Hunziker, 1995) [42]. In sampling, as long as the information provided by the interviewee expands opinions and perspectives, it is be added to the sample. Once very few or no new insights are extracted for the topic, the sampling process terminates [42]. For more insights on the design of theoretical sampling studies see [42] or [43]. This study selected 14 residents for interviews (2020.10.8-10.20) (Appendix A) to determine their landscape environment and preferences, and each interview lasted about $30 \mathrm{~min}$. Three people had lived in this area for 5 to 10 years and eleven people for more than 15 years. The interviewees included seven men and seven women, with two under 60 , seven from 60 to 65 , and five over 65 . The second step was to restore the past landscape space appearance more accurately and spatially quantify land use in the study area. Taking 2005 and 2019 as the time points, the land changes over a total of 15 years were reviewed (Figure 2). The third step was to obtain government policies and identify significant events in the study area to calibrate the content of interviews with residents to ensure accuracy. Therefore, this research used diversified information sources to obtain a comprehensive perspective so that the past description of the landscape environment had a degree of credibility.

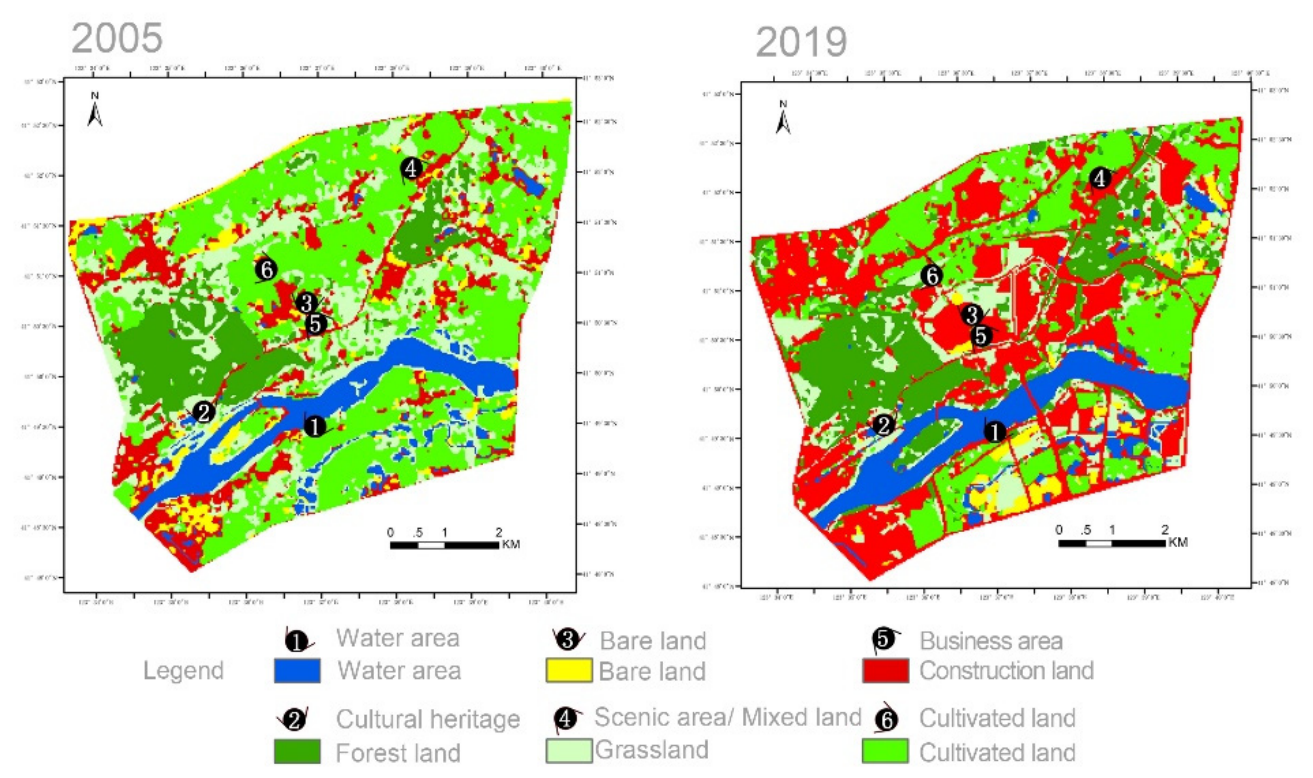

Figure 2. Locations of photos taken and land use analysis in 2005 and 2019.

\subsection{Content Analysis}

This study followed the steps described in Figure 3 (see Figure 1 in Bazrafshan et al., 2021) [44]. First, the content analysis method required interview data. After that, interview texts were transcribed (step a) and key sentences extracted (step b). Finally, steps b to $\mathrm{d}$ in Figure 3 were repeated to refine the data and generate research opinions [44-46]. This method has been applied to the research of Bazrafshan et al., 2021 [44], Meneghello (2021) [47], and Hunziker (1995) [42]. 


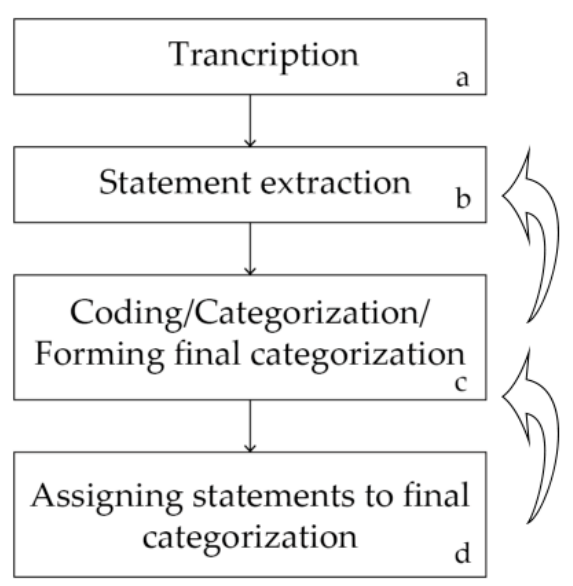

Figure 3. Schematic diagram of content analysis [44].

\subsection{Spatial Quantitative Analysis}

Ning et al. (2021) [2] previously conducted a detailed analysis of landscape spatial pattern in the study area and divided the land into six categories (construction land, cultivated land, forest land, water area, bare land, and grassland) (Figure 2). Construction land includes industrial land, roads, urban residential land, rural homesteads, and commercial land. Cultivated land includes irrigated land and dry land. Forest land includes trees, shrubs, and others. Water area includes rivers, lakes, and ponds. Bare land includes free land and sandy land. Grassland includes high, medium, and low coverage grassland. Remote sensing image interpretation was based on Landsat remote sensing images in 2005 and 2019 (Figure 2). The study used Fragstats 4.2 software to calculate the landscape index and select the LSI and AI indexes of the class level index for analysis. LSI is a shape index in which the larger the value, the more irregular the shape of the landscape tends to be [48]. AI indicates the spatial configuration of landscape components and the degree of aggregation of specific patch types [4]. These two indexes belong to the shape and convergence index. From these two indexes, we can see the change and degree of development.

\section{Results}

\subsection{Description and Opinions of Landscape Ecological Changes}

For discussion, coding steps, and key interviewee statements, please refer to Appendix A.

\subsubsection{Water Area}

The past landscape was divided into two dimensions: one was landscape elements (including water quality and quantity, riverbed, aquatic creatures, and riverside vegetation), and the other was spatial memory. Water quality and quantity examples included the following observations: the river was deep, only the flood season resulted in more water and domestic garbage. Riverbed assessment examples included the following observations: there were shoals and a sandpit, and the revetment was uneven. Aquatic creature examples include the following observations: fish were big and many. Riverside vegetation assessment examples included the following observations: the natural growth was chaotic and single-species. Spatial memory examples included free bathing on the riverbank, better air quality, and a more natural environment.

As seen from the spatial interpretation map (Figure 2), the land-use properties of the water area did not change from 2005 to 2019. The Shenyang Government has promulgated the "Shenyang Water Resources Management Measures" since April 1997 and began to attach importance to water protection. From the spatial data (Table 1), the water area increased from 476.64 ha in 2005 to 540.36 ha in 2019. The proportion of water area has increased to $10.08 \%$. Linked with the description of water quality and quantity in the interview, one interviewee stated, "the water used to be exiled naturally, and all the dirt would 
be washed away during the rainy season. However, now the river had more water, and the water surface was wider. It was because there was so much water in the reservoir!"

Table 1. Analysis of land use changes from 2005 to 2019.

\begin{tabular}{ccccc}
\hline Time & \multicolumn{2}{c}{2005} & \multicolumn{2}{c}{2019} \\
\hline Type & Area (ha) & Percentage (\%) & Area (ha) & Percentage (\%) \\
\hline Water area & 476.64 & $8.89 \%$ & 540.36 & $10.08 \%$ \\
\hline
\end{tabular}

From analysis of the landscape category index (Table 2), the LSI of the water area dropped from 9.92 to 8.63 , indicating that the shape of the water area changed from complex to simple. The AI index increased from 87.53 to 93.03 , indicating that the concentration of the water area increased, which can be linked to the description of the riverbed. Regarding this, one interviewee stated, "the past river was not too wide. It was all shallows, sand, and slopes. There were many sandpits, and people were afraid to walk along the river. There were sand digging machines, small and large pits. If you accidentally fall into the pit, you would drown".

Table 2. Class level index in 2005 and 2019.

\begin{tabular}{cccccc}
\hline & \multicolumn{3}{c}{ LSI } & \multicolumn{2}{c}{ AI } \\
\cline { 2 - 6 } & $\mathbf{2 0 0 5}$ & $\mathbf{2 0 1 9}$ & $\mathbf{2 0 0 5}$ & $\mathbf{2 0 1 9}$ \\
\hline Water area & 9.92 & 8.63 & 87.53 & 90.03 \\
\hline
\end{tabular}

Based on the content of the interview, spatial quantitative analysis, and the government's policy, the past landscape was better in air quality and more natural. The river was deep, there was much water in the rainy season, the fish in the water were big and numerous, and there was much domestic garbage. Residents could bathe freely on the banks of the river. The past riverbed had shallow sand beaches, sandpits, and uneven revetments. Natural vegetation grew disorderly and had a single species.

\subsubsection{Forest Land}

The past landscape was interpreted from two dimensions: landscape elements (vegetation and roads), and spatial memory. Vegetation was lush trees and there was little change in the forest environment. The road was narrow and uneven, with few landscape features. Spatial memory included fewer people in the past, no tourist attractions, no tickets, and all sides were accessible.

As seen from the spatial interpretation map (Figure 2), the forest land did not change much and could be correlated with vegetation from 2005 to 2019. Regarding this, one interviewee stated, "Dongling had not changed much, and there was no change in the scenic area. The changes were also the trees in the scenic area. The centuries-old trees were cut down when the early government did not protect this place. However, about 20 years ago, it began to be protected, and the scenic area had not changed much".

Based upon the interview content, and spatial quantitative analysis, we found that not much had changed from the past to the current landscape. Previously, it was not a tourist attraction, with no tickets, few visitors, lush vegetation, and centuries-old trees. However, the roads were narrow and uneven, with few landscape features.

\subsubsection{Bare Land}

The past landscape was interpreted from landscape elements including land cover and soil. Land cover was mixed villages, waste grassland, and cultivated land. The soil was mainly mud, commonly known as a mud village.

From analysis of landscape category index (Figure 2), land use in 2005 was a mixture of cultivated land, grassland, forest land, and construction land. One interviewee stated, "there used to be a village called Luanni village. They were all small bungalows, but they were later 
demolished". In addition to waste grassland, there was a small part of forest land in the place. In 2019, the land became construction land when, from December 2008, the China Travel Construction Group began to build China Travel International Town.

Based on the content of the interview, spatial quantitative analysis, and the government's policy (Figure 2), the past landscape was very different compared with the current landscape. The past landscape was a mud village dominated by cultivated land, grass wasteland, forestland, and mud.

\subsubsection{Mixed Land}

The past environment was interpreted from the landscape elements (including land cover, roads, and animals). Land cover was mainly cultivated land, and there used to be villages there. Roads were mainly dirt roads. There were creatures in the river, and poultry was raised at home.

From analysis of landscape category index (Figure 2), land cover in 2005 consisted of construction land, bare land, grassland, and cultivated land. In September 2004, Shenyang successfully bid for the World Horticultural Exposition in April and October of 2006. The area served as the main entrance of the Expo, and construction occurred. In 2019, it was composed of a large area of construction land and grassland. The development can be related to land cover. Regarding this, on interviewee stated, "this place was used for farming, and the farmland was mainly dry land, and corn was grown. It used to be a village, with undulating hillsides, and dirt roads, mainly for growing crops, mostly corn".

Based on the content of the interview, spatial quantitative analysis, and the government's policy, the past landscape was very different compared with the current landscape, changing from construction land, bare land, grassland, and cultivated land to a parking function area dominated by construction land. The past landscape was a village with rivers passing through, natural creatures in the river, and cultivated land as the mainstay. The village roads were mainly dirt roads, and the villagers would raise poultry in their homes.

\subsubsection{Construction Land}

The past environment was interpreted from landscape elements including land cover, soil, and roads. Land cover included villages and cultivated land and grass wasteland. The soil was muddy and low-lying. The roads were cement road or dirt roads.

From analysis of landscape category index (Figure 2), in 2005, the land cover was a mixture of construction land, cultivated land, water area, waste grassland, and bare land. In December 2008, the China Travel Construction Group began to build the CTS outlet business center. In 2019, the land cover became construction land and development is sufficiently related to land cover. Regarding this, one interviewee said, "the land had water before, and it felt like a reed pond. There were also desolate cultivated land. And the land was a village before, with dilapidated houses and crops".

Based upon the content of the interview, spatial quantitative analysis, and the government's policy, the past landscape was significantly different compared with the current landscape, changing from a mixture of construction land, cultivated land, water area, waste grassland, and bare land, to construction land. The past consisted of villages and puddles. The roads were mainly cement roads or dirt roads. The land was muddy and low-lying, and there were mixed planted cultivated land and grass wasteland.

\subsubsection{Cultivated Land}

The past environment was interpreted from landscape elements including land cover and rivers. Land cover was mainly cultivated land, with little change. Rivers were clear and wide. From the perspective of spatial memory, land in the past provided residents with production and living needs.

Figure 2 shows that between 2005 and 2019, although some changes are not visible, cultivated land was converted to construction land. This can be related to land cover, in that one interviewee stated, the place in the picture had not changed much, but houses were 
built behind, and high-voltage wires had been added. It used to be a cornfield, vegetable field, and cultivated land mixed with forests.

From the landscape category index (Table 3), the cultivated land area decreased from 2028.69 ha in 2005 to 1118.61 ha, and the proportion of cultivated land also decreased to $20.86 \%$, a significant reduction trend. One interviewee said, the place used to be cultivated land, which in the photo had not changed much, but the surrounding area had changed a lot. Now the cultivated land had decreased a little.

Table 3. Analysis of land use changes from 2005 to 2019.

\begin{tabular}{ccccc}
\hline Time & \multicolumn{2}{c}{2005} & \multicolumn{2}{c}{2019} \\
\hline Type & Area (ha) & Percentage (\%) & Area (ha) & Percentage (\%) \\
\hline Cultivated land & 2028.69 & 37.84 & 1118.61 & 20.86 \\
\hline
\end{tabular}

From the landscape category index (Table 4), the LSI of cultivated land decreased from 17.77 to 17.31, indicating that the shape of cultivated land became simplified. The AI dropped from 88.73 to 85.24 , indicating that the concentration of cultivated land has decreased. One interviewee said, "the place in the picture had not changed much. It turns out that this place was cultivated land, with undulating terrain around it, most of which were also planted with corn. However, there were still significant changes around this cultivated land. The Environmental Protection Agency moved here more than ten years ago".

Table 4. Class level index in 2005 and 2019.

\begin{tabular}{lcccc}
\hline & \multicolumn{3}{c}{ LSI } & \multicolumn{2}{c}{ AI } \\
\cline { 2 - 5 } & $\mathbf{2 0 0 5}$ & $\mathbf{2 0 1 9}$ & $\mathbf{2 0 0 5}$ & $\mathbf{2 0 1 9}$ \\
\hline Cultivated land & 17.77 & 17.31 & 88.73 & 85.24 \\
\hline
\end{tabular}

Based upon interviews and spatial quantitative analysis content, the study found that the past environment was similar to the current environment, which is mainly farming. The rivers that cross the cultivated land were wide and had clear water, which provided the residents with the needs of production and life, and a place for the residents to bathe.

3.2. Reasons for Preferring Past and Current Landscape

3.2.1. Results of Discussions from the Perspective of Land Types

For discussion, coding steps, and key interviewee statements, please refer to Appendix A.

1. Water Area

- There are three preference factors for the past water area. The first is that the landscape was highly natural, whereas today's artificially carved landscapes seems unnatural. The second is that the skyline was flat with a broad horizon. The third is less pollution.

- There are three preference factors for the current water area. The first is environmental management, including artificial repairs and an orderly environment, such as planning parks to be cleaner and richer in vegetation types. The second is water area optimization: the water is not smelly, but the water is not clear. The third is that the convenience of life is better: transportation is improved, bridges have been built, and transportation is convenient. Moreover, the interaction is better and interpersonal communication is convenient.

2. Forest Land

- The reasons for preferring the past environment can be divided into three dimensions. Accessibility was better, recreation was more accessible, easy to reach, and with no restraints. The landscape was more natural, and there were many wild animals. The landscape had a good sense of beauty and continuity. 
- The reasons for preferring the current environment can be divided into two dimensions. Artificial repairs and an orderly environment such that vegetation is more regular and diverse, functional areas are reasonable, and the roads are tidy. The environment experience is enhanced, and it is a place for relaxation.

3. Bare Land

- The reasons for preferring the past environment can be divided into three dimensions. The environment had less pollution, better air, and less noise. The skyline was flat, and viewpoints were broad. It was more natural with many wild animals and plants.

- Preference for the current environment is mainly based on environmental management, convenient lifestyle, clean environment, and supporting communities.

4. $\quad$ Mixed Land

- There are three preference factors for the past environment. The landscape was more natural and there were few people. There was better accessibility, greater freedom, easy access, and freer routes for recreation. Organic agricultural production and self-cultivation was healthier, with less chemical fertilizers and pesticides.

- There are two preference factors for the current environment. The sense of environmental experience is enhanced, and the scenic area can be used as a place for decompression from employment in the city. There is environment management, artificial repairs, an orderly environment and regular vegetation of various types.

5. Construction Land

- There are four preference factors for the past environment. The landscape had natural beauty with abundant vegetation and animal sounds. There was less pollution, fewer people, good air, and less noise. The skyline was flat, and the field of view was broad. There was a sense of attachment, resulting in a feeling of nostalgia.

- There are two preference factors for the current environment. Enhancement of a sense of environmental experience, more employment, and being closer to the lives of contemporary people. The landscape has beauty.

\section{Cultivated Land}

There are six preference factors for the past environment. There was less pollution, fewer people, and a quiet environment. There was a good sense of environmental experience, landscape appreciation, and relaxation. The landscape was very natural, and there were many animals. There was organic agricultural production, with good food safety and low fertilizer use. There was a sense of attachment, resulting in a feeling of nostalgia. The skyline was flat, and the field of view was broad.

Because the study area's environmental changes were not obvious, the residents' preference descriptions mostly focused on memory and did not mention the current landscape preference.

\subsubsection{Urban Fringe Interpretation of Landscape Preferences}

When evaluating the past six landscape environment preferences, eight factors made residents prefer the past landscape environment (Table 5): greater naturalness, less pollution, a flat skyline, high accessibility, organic agricultural production, strong place attachment, good landscape beauty, and a good sense of landscape experience. Four factors made residents prefer the current landscape environment (Table 5): good environmental management, a good sense of landscape experience, the convenience of life, and good landscape beauty. 
Table 5. Summary of reasons for environmental preference.

\begin{tabular}{|c|c|c|c|c|c|}
\hline \multicolumn{4}{|c|}{ Past } & \multicolumn{2}{|c|}{ Current } \\
\hline Code & $\begin{array}{c}\text { Number of } \\
\text { Photos }\end{array}$ & Code & $\begin{array}{c}\text { Number of } \\
\text { Photos }\end{array}$ & Code & $\begin{array}{c}\text { Number of } \\
\text { Photos }\end{array}$ \\
\hline $\begin{array}{l}\text { High } \\
\text { naturalness }\end{array}$ & All & $\begin{array}{l}\text { Organic } \\
\text { agricultural } \\
\text { production }\end{array}$ & 4.6 & $\begin{array}{l}\text { Good envi- } \\
\text { ronmental } \\
\text { manage- } \\
\text { ment }\end{array}$ & 1.2.3.4 \\
\hline $\begin{array}{l}\text { Less } \\
\text { pollution }\end{array}$ & 1.3.4.5 & $\begin{array}{l}\text { Strong place } \\
\text { attachment }\end{array}$ & 5.6 & $\begin{array}{c}\text { Good sense } \\
\text { of landscape } \\
\text { experience }\end{array}$ & 2.4 .5 \\
\hline Flat skyline & 1.2.5.6 & $\begin{array}{c}\text { Good landscape } \\
\text { beauty }\end{array}$ & 2 & $\begin{array}{c}\text { The } \\
\text { convenience } \\
\text { of life }\end{array}$ & 1.2 .3 \\
\hline $\begin{array}{l}\text { High } \\
\text { accessibility }\end{array}$ & 2.4 & $\begin{array}{l}\text { Good sense of } \\
\text { landscape } \\
\text { experience }\end{array}$ & 6 & $\begin{array}{c}\text { Good } \\
\text { landscape } \\
\text { beauty }\end{array}$ & 5 \\
\hline
\end{tabular}

Therefore, by cross-comparing past and present preferences, the landscape preferred by residents was summarized. This can be divided into three categories and ten dimensions (Figure 4).

\begin{tabular}{|l|l|} 
Landscape \\
preference
\end{tabular}

Figure 4. Classification and interpretation of residents' preferred landscape.

1. Natural factors

- Residents' descriptions of high naturalness are divided into a good landscape environment, little artificial intervention, natural beauty, and more wild animals and plants. Perceived naturalness is based on the naturalness felt by the subject [49]. Hull et al. (2001) [50] indicated that perceived naturalness includes health and authenticity, among other factors, in which authenticity is described as not artificially arranged. Tveit et al. (2006) [34] revealed that the dimensions of perceived naturalness include integrity, wilderness, and naturalness, among other factors, in which integrity refers to the absence of perceived interference and damage, and naturalness refers to natural elements in the environment. 
Assessing the coding and interpreting the interview content, and making comparisons with existing research, the study found that the naturalness as a factor had reliability and validity.

- Residents believe that less pollution is defined as fewer people, better air, less noise, and less pollution. Words associated with less pollution in previous studies included disturbance [34,51] and serene [52]. The Landscape Institute and Institute of Environmental Management Assessment (2013) [51] defined the negative impact of landscape change disturbance as changes completely different from the original landform, scale, and pattern that permanently reduce past value characteristics. Grahn and Stigsdotter (2010) [52] defined serene as being in an undisturbed, quiet, and calm environment and found that serene was a key factor in humans' preferred urban green spaces. In this study, due to the changes in the landscape spatial pattern, the past landscape's integrity was fragmented, which created problems in the current environment and making the public feel that it is noisier and polluted.

- Residents think that a flat skyline provides a broad landscape view. Similar words are associated with the flat skyline in previous studies, such as prospect [31] and visual scale [34]. Appleton (1996) [31] believed that prospect related to a broad field of view, and that controlling this would enable people to discover danger in time. It was an instinctive and conscious response to the living environment. Tveit et al. (2006) [34] defined visual scale as visibility and openness, directly related to landscape preferences [53,54]. Therefore, the public's preference is directly related to the skyline's flatness, and it is also a human instinct to respond to a safe environment.

- Organic agricultural production is described as self-cultivation, which is healthier, and with less fertilizer use. Organic farming and production positively affect soil and ecological protection [55]. In the Dutch agricultural open space, the combination of production value and other "green" values has contributed to the success of farmland protection [56]. In this study, due to changes in the basic environment, the residents who originally had cultivated land lost their farming rights, and agricultural food safety was beyond their control.

\section{Human factors}

- High accessibility is described as ease of reach, great freedom, and freer routes of action. Dalvi and Martin (1976) [57] and Song (1996) [58] believed that accessibility related to degree of easy access, specifically with respect to the distance between destinations and place of residences, the environment, and the temporal and spatial autonomy of people [59]. Accessibility is one of the essential indicators for the public in choosing an event venue. When the event venue is close to residences or has convenient transportation and can be easily reached, the venue will be readily selected as the event destination [60].

- Good environmental management is described as artificial repair, an orderly environment, and environmental problems can be managed. Tveit et al. (2006) [34] regarded management as a key element of visual landscape management and defined it as a sense of order. Active and meticulous management would encourage humans to care about the landscape. Similar words have been associated with management in previous studies, such as care [61] and careful management [62]. "Aesthetic of care" and "cues of care" are mowing, trimming vegetation, trees, flowers, and providing neat garden roads [61]. van-Mansvelt and Kuiper (1999) [62] believed that the land could be well maintained and taken care of by good maintenance of the farming elements in the landscape. In our study, environmental management results (artificial repair, orderly environment) are similar to those of previous research. However, the results cover more range than in previous research, such as adding environmental governance. 
- Convenience of life is described as improving people's transportation convenience, life convenience, and interpersonal interaction. Convenience of life refers to the convenience of residents' daily use of public and service facilities. The public service facilities necessary for daily life were divided into two categories: daily shopping and dining facilities, in a previous study [63]. In this study, convenience of life extended to convenient transportation and interpersonal communication, which is the landscape that people prefer today.

3. Spatial perception

- Strong place attachment is described as providing people with a nostalgic life and environment. Place attachment refers to the emotional bond between people and place [64] and connects with the local natural environment [65]. Gobster (1999) [66] extended the concept of landscape quality assessment to the link with personal emotions, including the environment and human-environmental experience, memories, and imagination. In previous studies, similar words related to this included a sense of place $[9,22]$. Sense of place postulates that human perception extends to the meaning of the landscape [22] and is shaped by forces of nature, humanity, and society. People experience the shape, line, color, and quality of landscapes through the five senses, eliciting imagination memories and thus creating unique feelings about their experienced landscape [9].

- Landscape beauty is described as visual beauty, which means that beauty and the landscape have a sense of continuity. The landscape's beauty is an experience based on the visible and the form, all described by words such as "beautiful and attractive." Tveit et al. (2006) [34] regarded coherence as a key factor of visual landscape management and defined it as a reflection of a scene's unity. Kaplan and Kaplan (1989) [33] believed that a coherent landscape environment could help people understand the environment by providing a sense of order to guide the observer's attention and use it as a landscape evaluation indicator [33,67]. At the same time, continuity also reflects the correspondence between land use and natural conditions in a region.

- A good sense of landscape experience considers that cultivated land, cultural heritage, scenic spots, and low-density commercial districts do not only provide a way to appreciate the landscape but also serve as places for urban people to relieve stress, provide places for employment, and are close to contemporary life. Grammatikopoulou et al. (2012) [68] pointed out that organic farming provides a new landscape appreciation, as in our results. Landscape experience involves people's explorations, including internal operation, experience, and the results of external stimuli acting on people [69]. Cultivated land, cultural heritage, scenic spots, and low-density commercial districts can enhance landscape experience. Residents believe that such places can bring them a sense of relaxation, closer to their needs.

\section{Discussion}

\subsection{Past Environment Research Methods}

This study provides a feasible method for exploring the past landscape environment without a great amount of image data support. This method can serve as a reference for other regions of the world facing similar problems. However, in the past, most researchers used past and present image resources as the starting point of their research to analyze different aspects of landscape discussions [70,71].

Past landscapes, in which land use was relatively simple, might not change much. In the absence of map resources, researchers can employ the narrative interview method of the experiential paradigm, spatial interpretation maps, spatial data analysis (area and percentage), spatial quantitative landscape index (LSI $\backslash \mathrm{AI}$ ), government-related policies, and significant events, to explore past landscapes. If past land use was more complicated or the environment significantly changed, it would be worth employing the narrative interview 
method of the experiential paradigm, spatial interpretation maps, government-related policies, and significant events to explore past landscapes, thereby enhancing credibility.

\subsection{Landscape Preferences in Urban Fringe Areas}

This study found that the landscapes preferred by residents in urban fringe areas can be divided into three categories and ten dimensions. In previous studies, Tveit et al. (2006) [34] summarized visual evaluation indicators for analyzing landscape changes, in which nine key concepts were assessed: management, continuity, interference, history, visual scope, imageability, complexity, naturalness, and transient state. Grahn and Stigsdotter (2010) [52] proposed eight perception dimensions of people in green urban spaces: nature, culture, prospects, society, space, species richness, refuge, and tranquility. van den Born et al. (2019) [72] studied Dutch residents' assessments of river landscape changes before and after major projects. They found that residents preferred a sense of place identity and connection with nature. Although different methods were used from previous studies, and the groups and the environment were different, the results were very similar. However, each has its uniqueness. For example, organic agricultural production and convenience of life were not previously mentioned, so these factors supplement the existing research. In addition, our study can also guide landscape assessment and provide a theoretical basis as the foundation for the measurement variables of the assessment factors.

The natural factors of this study include great naturalness, less pollution, a flat skyline and organic agricultural production. Other studies have confirmed the relevance and importance of landscape naturalness and people's health and well-being. Năstase et al. (2019) [73] in Romania found that even people who prefer urban life prefer places with greater naturalness of the landscape. Maas et al. (2006) [74] in the Netherlands found a relationship between green space and people's health. Green space is very important for explaining the health status of urban and rural residents. Lee and Maheswaran (2011) [75] also confirmed that green space is beneficial to physical and mental health, well-being and social and economic benefits. Therefore, retaining the naturalness of the landscape is consistent with the results of this study. However, this study found that the pollution situation, visual breadth, and organic agricultural production in urban fringe areas also need attention.

The human factors of this study include high accessibility, environmental management, and living convenience. Other studies have confirmed the importance of accessibility and environmental management from different perspectives. Lee and Maheswaran (2011) [75] believed that accessibility and spatial characteristics are decisive factors for sports activities and green space use. In addition, it has been stated that creating a cleaner, safer, and environmentally friendly public space has a positive effect on people's health. Japelj et al. (2016) [76] in Slovenia pointed out that people's preferred forest environment includes a preference for forest vegetation, a preference for setting up walking paths, a preference for open forests, and a preference for maintaining road signs and information boards. Polat and Akay (2015) [77] in Turkey found that the width of sidewalks, vegetation composition, and color should be effectively managed. This is consistent with the results of our study. Convenience of life is an essential factor in evaluating livable cities and residents' quality of life [63], which also needs attention.

The spatial perception factor included in this study includes strong place attachment, landscape beauty, and a sense of landscape experience. People usually have a sense of place attachment to a familiar area. However, even a space that has never been visited may create a sense of place attachment with an iconic value [73]. Polat and Akay (2015) [77] believed that improving the visual quality of urban recreational areas would promote the physical structure and layout of the city and provide residents with better comfort and a better psychological environment. Năstase et al. (2019) [73], in Romanian research, found that people's preference for the natural environment is related to natural leisure activities such as walking in the forest and observing nature. Our research agrees that forest areas are favored, but also found that cultivated land, cultural heritage, scenic spots, 
and low-density business districts are also preferred environments. Cultivated land has changed from providing food and fuel supply services to cultural services, which have both leisure, tourism, cultural heritage and aesthetic functions [78], findings similar to the results of this study. The spatial perception of urban fringe areas is very important.

Compared with other studies, this study proposes planning from the perspective of landscape preference (natural factors, human factors, and spatial perception) for the future development of urban fringe areas. The plan is relatively comprehensive and specific and has its particularity. This study shows that the landscape that residents prefer is highly specific. If small factors are ignored, the needs and wishes of residents may not be met. The importance of residents' perception of changes in the landscape environment plays a vital role in planning and environmental restoration [27]. It is necessary to pay attention to landscape naturalness, accessibility, environmental management, place attachment, landscape beauty, and landscape experience in urban fringe areas. The results are consistent with previous studies. At the same time, our research shows that environmental pollution, visual breadth, organic agricultural production, and convenience of life in urban fringe areas also require attention. At present, the relationship between these four factors and urban fringe landscape preferences is limited. Our research shows that development should consider its natural environment, carry out limited artificial environment construction, and pay attention to spatial perception.

\section{Conclusions}

In recent years, significant changes have taken place in the environment of urban fringe areas. As images of the past landscape were insufficient, this study used landscape narrative interviews of the experience paradigm, spatial quantification, government policies, and major event methods to obtain past perceptions of the six environments evaluated. The method of this research can be extended to areas with similar conditions. The study method can also be applied to assess the environment in urban and rural areas.

Our research used content analysis to analyze the content of interviews to obtain past and present environmental preferences. The method can be applied to other qualitative studies. Our analysis found that people's preferred environments had common features divided into three categories and ten dimensions. Among them organic agricultural production and convenience of life had not been previously considered, so these factors supplement the existing research, and our study will form the theoretical basis of urban fringe landscape preferences. From the perspective landscape preferences, a plan for future urban fringe area development is proposed, which respects the natural environment while creating an appropriate artificial environment and focusing on spatial perception.

Author Contributions: Conceptualization, F.N. and S.-J.O.; methodology, F.N. and S.-J.O.; software, F.N.; validation, F.N. and S.-J.O.; formal analysis, F.N. and S.-J.O.; investigation, F.N.; resources, F.N.; data curation, F.N.; writing-original draft preparation, F.N.; writing-review and editing, S.-J.O.; visualization, F.N.; supervision, S.-J.O.; project administration, S.-J.O. All authors have read and agreed to the published version of the manuscript.

Funding: This research received no external funding.

Conflicts of Interest: The authors declare no conflict of interest. 


\section{Appendix A}

Semistructured interview questionnaire

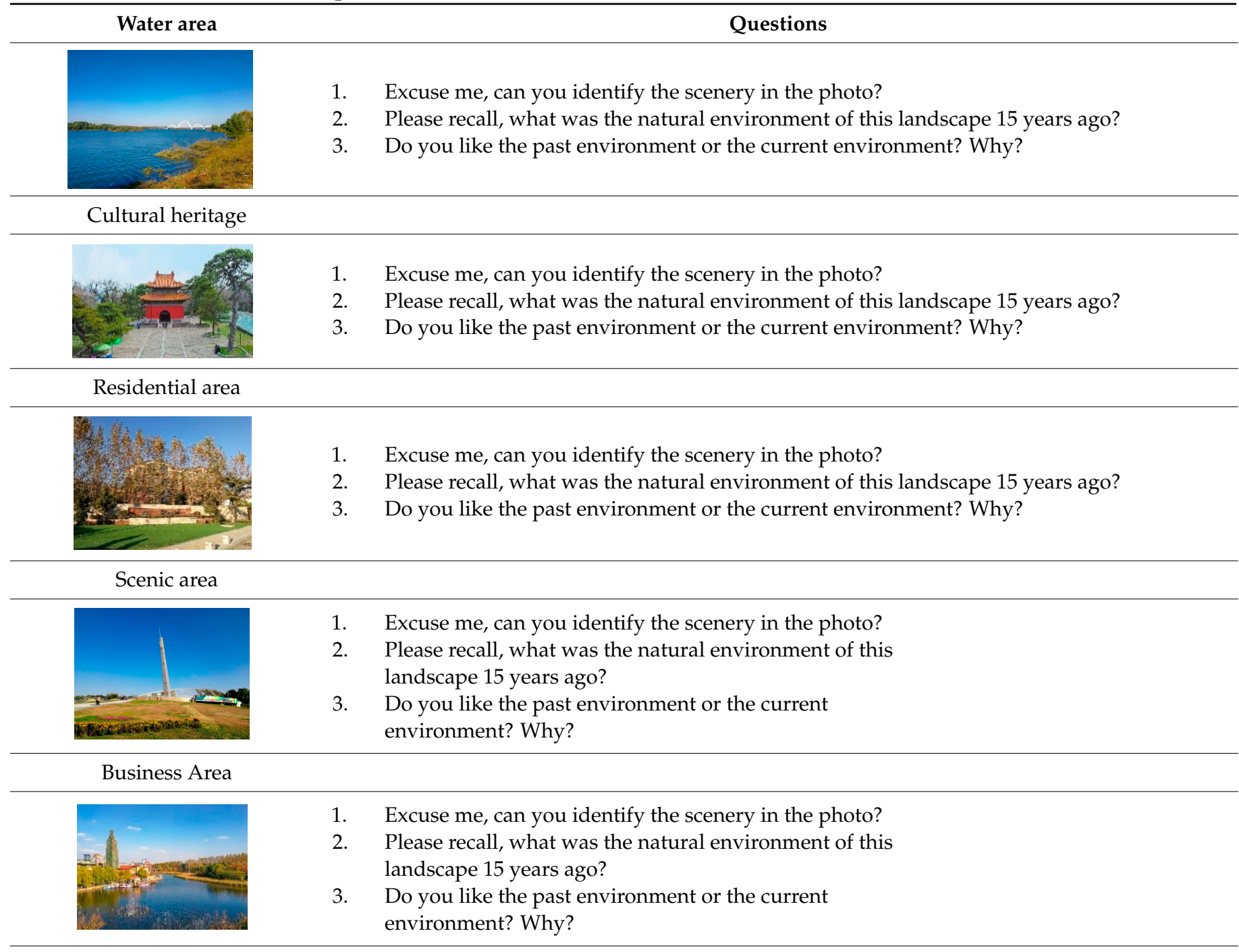

\section{Cultivated area}

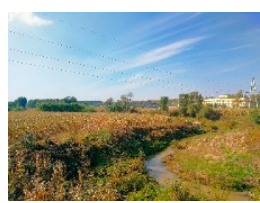

1. Excuse me, can you identify the scenery in the photo?

2. Please recall, what was the natural environment of this landscape 15 years ago?

3. Do you like the past environment or the current environment? Why?

Basic information of the interviewee:

1. Gender: Male/Female 2. Age 3. Profession

4. Are you a resident of this area or the surrounding area? Yes/No

5. Length of residence: Less than 5 years, $6-10$ years, $11-15$ years, more than 15 years 


\section{Appendix B}

\begin{tabular}{|c|c|c|c|}
\hline Land Use & Dimension & $\begin{array}{c}\text { Original } \\
\text { Encoding }\end{array}$ & The Key of Interviewee's Statement \\
\hline \multirow{5}{*}{$\begin{array}{l}\text { Water } \\
\text { area }\end{array}$} & \multirow{4}{*}{$\begin{array}{c}\text { Landscape } \\
\text { elements }\end{array}$} & $\begin{array}{l}\text { Water quality and } \\
\text { quantity }\end{array}$ & $\begin{array}{l}\text { - In the past, the natural water environment was dirty, and there was } \\
\text { much domestic garbage. } \\
\text { The past water was not as full as it is now. Sometimes when it rained } \\
\text { heavily, the water would overflow to the shore. During the dry season, } \\
\text { the riverbed was exposed on the shore. }\end{array}$ \\
\hline & & Riverbed & $\begin{array}{l}\text { - There used to be sandpits along the river, and there used to be people } \\
\text { mining sand by the river. } \\
\text { There was rubbish on the shore and sand was mined with a sand } \\
\text { dredger, all of which created uneven revetments. }\end{array}$ \\
\hline & & Aquatic creatures & $\begin{array}{l}\text { - There used to be more types of fish in the water, and the current was } \\
\text { rapid. There were big carps in the water ten years ago, but now they } \\
\text { are gone. } \\
\text { - In the past, there were many fish in the river, and they were huge. }\end{array}$ \\
\hline & & $\begin{array}{c}\text { Riverbed } \\
\text { vegetation }\end{array}$ & $\begin{array}{l}\text { - The riverbank was full of weeds, and there was no road. Sometimes } \\
\text { when you went to the riverbank and walked out of the road, the weeds } \\
\text { would hurt your legs. }\end{array}$ \\
\hline & $\begin{array}{l}\text { Spatial } \\
\text { memory }\end{array}$ & Spatial memory & $\begin{array}{l}\text { - In the past, I would take a bath by the river because of the limited } \\
\text { family conditions in the summer, and it was very comfortable. } \\
\text { - There was still a vague memory. Before the bridge was built, the } \\
\text { environment was natural. The air quality was better than it i now. }\end{array}$ \\
\hline \multirow{3}{*}{ Forest land } & \multirow{2}{*}{$\begin{array}{l}\text { Landscape } \\
\text { elements }\end{array}$} & Vegetation & $\begin{array}{l}\text { - Dongling is the same as it was, with no major changes, nothing more } \\
\text { than a lot of modern infrastructures. } \\
\text { The changes were not so big, because it was a historical site, the forest } \\
\text { protection was okay, but a lot of old trees were also cut down in the } \\
\text { early days. }\end{array}$ \\
\hline & & Roads & $\begin{array}{l}\text { - The road was relatively narrow, the terrain was not as flat as it is now, } \\
\text { and did not have so many functions that are needed now; for example, } \\
\text { squares and parking, etc. } \\
\text { This scenic spot was not so beautiful before. It used to be a bus station. } \\
\text { The place was dug later for sand mining; a lotus pond was built on } \\
\text { that land. }\end{array}$ \\
\hline & $\begin{array}{l}\text { Spatial } \\
\text { memory }\end{array}$ & Spatial memory & $\begin{array}{l}\text { - Twenty years ago, this was not such a scenic spot as it is now, and there } \\
\text { - } \quad \text { It ware not too many people visiting. } \\
\text { park. I always went there to play. There used to be no entrance fees. } \\
\text { You could enter the park from all sides. There was no scenic fence. }\end{array}$ \\
\hline \multirow[t]{2}{*}{ Bare land } & \multirow[t]{2}{*}{$\begin{array}{l}\text { Landscape } \\
\text { elements }\end{array}$} & Land cover & $\begin{array}{l}\text { - In my memory, this land used to be either vegetable land, wasteland, or } \\
\text { cultivated land. } \\
\text { However, some places could also grow crops, some land was } \\
\text { abandoned, and some had weeds. } \\
\text { The place used to have a village and cultivated land, but the soil here } \\
\text { was mostly clay, so you couldn't grow much if you planted. }\end{array}$ \\
\hline & & Soil & $\begin{array}{l}\text { - In the past, this place was called Xiluanni village. There were } \\
\text { dilapidated farmhouses, and the soil was all mud. The terrain was low, } \\
\text { and there would be water in the summer when there was heavy rain. }\end{array}$ \\
\hline
\end{tabular}




\begin{tabular}{|c|c|c|c|}
\hline Land Use & Dimension & $\begin{array}{l}\text { Original } \\
\text { Encoding }\end{array}$ & The Key of Interviewee's Statement \\
\hline \multirow[b]{3}{*}{ Mixed land } & \multirow[b]{3}{*}{$\begin{array}{l}\text { Landscape } \\
\text { elements }\end{array}$} & Land cover & $\begin{array}{l}\text { - It turned out to be barren land, where corn was grown. Later, the place } \\
\text { started planting trees and gardens, a botanical garden. } \\
\text { It turned out to be a vegetable field, farmland, dry land, wasteland, and } \\
\text { there was a village before. }\end{array}$ \\
\hline & & Roads & $\begin{array}{l}\text { - In the past, this was a village. The undulating hillsides had dirt roads. } \\
\text { They mainly grew crops, mostly corn. } \\
\text { - It turned out to be farmland. It's my farmland and dirt roads. }\end{array}$ \\
\hline & & Animals & $\begin{array}{l}\text { - In the past, people in this place were farmers. They depended on } \\
\text { farming for their livelihoods. They also raised livestock, such as horses, } \\
\text { cows, sheep, chickens, and ducks. It was a very rural life. } \\
\text { Now the river has less water. There used to be fish and crabs. At that } \\
\text { time, the government encouraged the people to plant linsey. Linsey } \\
\text { was mainly used for spinning. Linsey needs to be soaked for a certain } \\
\text { number of days before it can be peeled off and was toxic. After the } \\
\text { water entered, the animals in the water were gone. In the past, every } \\
\text { household used to raise chickens, ducks, cattle, and poultry. }\end{array}$ \\
\hline \multirow{3}{*}{$\begin{array}{l}\text { Constr- } \\
\text { uction } \\
\text { land }\end{array}$} & \multirow{3}{*}{$\begin{array}{l}\text { Landscape } \\
\text { elements }\end{array}$} & Land cover & $\begin{array}{l}\text { - It was an abandoned land with natural puddles and uneven heights. } \\
\text { - The land had water, mud pits, and houses, bungalows, and brick } \\
\text { houses. The shantytowns were later relocated. }\end{array}$ \\
\hline & & Soil & $\begin{array}{l}\text { - The land had water before, and there would always be water in the low } \\
\text { terrain, which might be related to the nature of the clay soil. }\end{array}$ \\
\hline & & Roads & $\begin{array}{l}\text { - In the past, the place was a mud village. The road was also a dirt road, } \\
\text { which was relatively narrow. } \\
\text { - Some of the roads were cement slab oil roads, and some were dirt roads. } \\
\text { The lake was not that big before, but it was built and enlarged a } \\
\text { little later. }\end{array}$ \\
\hline \multirow{3}{*}{$\begin{array}{l}\text { Cultiva-ted } \\
\text { land }\end{array}$} & \multirow[b]{2}{*}{$\begin{array}{l}\text { Landscape } \\
\text { elements }\end{array}$} & Land cover & $\begin{array}{l}\text { - Cultivated land behind the Environmental Protection Agency has not } \\
\text { changed much. }\end{array}$ \\
\hline & & Rivers & $\begin{array}{l}\text { - The river was clear before, but now the water is a bit muddy. } \\
\text { - The river was named Mantang River. In the past, there were fish and } \\
\text { shrimp in the water. The water quality was much worse. There were so } \\
\text { many buildings around, and the sewage was discharged. You might see } \\
\text { that the discharged sewage was clean, but there was still some damage. }\end{array}$ \\
\hline & $\begin{array}{l}\text { Spatial } \\
\text { memory }\end{array}$ & Spatial memory & $\begin{array}{l}\text { - The river was called Mantang River. The river in the past was a little } \\
\text { wider than now. There would be small fishes and shrimp. Back then, I } \\
\text { would go to the river to wash vegetables, and even bathe. Now it is } \\
\text { destroyed. Residents in the surrounding nursing homes and other } \\
\text { residents drained the sewage into it, which caused stinky drains. } \\
\text { In the past, I would take a bath by the river in summer. The bottom of } \\
\text { the river was sand, all clear water, and fine sand. I used to wake up at } \\
\text { 4:30 and go for early work at } 6 \text { o'clock. Then I would arrive in the } \\
\text { evening and go to the river to wash my face and take a bath. Finally, I } \\
\text { went home for dinner. }\end{array}$ \\
\hline
\end{tabular}




\section{Appendix C}

\begin{tabular}{cccc}
$\begin{array}{c}\text { Land } \\
\text { Use }\end{array}$ & Stage & $\begin{array}{c}\text { Original } \\
\text { Encoding }\end{array}$ & The Key Interviewee Statements \\
\hline
\end{tabular}

- I preferred the past environment, liked the beauty close to nature, not the artificial landscape.

Highly nature - $\quad$ Now they are all artificially made landscapes. They are not as comfortable as before. No matter how they were made, they are fake, not natural, and the water quality is not good.

- I used to live here and walked by the river. I couldn't see the tall buildings at all.

Sky line What I saw was the bungalow. Whenever there was sunrise or sunset, I would come

Past to the river to see the scenery. Some buildings over there were demolished shortly after they were built. Because of geological problems, the buildings had to be demolished, which is really a waste of resources.

- The river in the past was less polluted because the city didn't develop on such a large scale. Now there is industrial wastewater, and even if treated, it would still be polluted. Besides, there are more residents here. The natural environment

Less pollution was destroyed.

- However, such construction along the river would destroy the natural environment. For example, building the bridge destroyed aquatic life and left construction

Water garbage.

area

Current
- $\quad$ Before it was built, it was not as neat and standardized as it is now. It wasn't cultivated land before, and there was no manual repair. It looked primitive, crude, and wild. After the reconstruction, it became more standardized, tidy.

Environment management

- It feels that the riverbank is now more regular and has become a park, where you can go in, it is still very clean, and the road has much more green vegetation.

- In the past, the river had a foul smell because all the sewage along the river was

Environment

optimization to see to the bottom.

- The river quality had improved because the river was cleaned, and the monitoring of sewage along the river was strict.

- The bridge was built around 2012. After the bridge was built, I felt the

The convenience transportation and life were much more convenient. In addition, there was no of life damage to the natural environment. People's awareness of environmental protection is rising, but I feel that the bridge was a landscape feature.

- I like the current environment of the riverside park. The park is very beautiful, and I can go to the riverside to bask in the sun. There are activities for the elderly in the riverside park, and I also have people to chat with. 


\begin{tabular}{|c|c|c|c|}
\hline $\begin{array}{l}\text { Land } \\
\text { Use }\end{array}$ & Stage & $\begin{array}{l}\text { Original } \\
\text { Encoding }\end{array}$ & The Key Interviewee Statements \\
\hline \multirow{5}{*}{$\begin{array}{l}\text { Forest } \\
\text { land }\end{array}$} & \multirow{3}{*}{ Past } & $\begin{array}{l}\text { High } \\
\text { accessibility }\end{array}$ & $\begin{array}{l}\text { - In the past environment, I felt more comfortable, I could go in all directions, and I } \\
\text { could turn around as I wanted. Now I can't go in at will. There ae tickets sold, and } \\
\text { some places we are not allowed to enter. } \\
\text { I used to go there, and I could go in from the back without tickets and railings. Now } \\
\text { it doesn't work. There are only a few entrances. But it was good to go to the oxygen } \\
\text { bar to breathe fresh air and see the scenery. }\end{array}$ \\
\hline & & Highly nature & $\begin{array}{l}\text { - I liked the past environment, closer to nature. There would be potherbs on the } \\
\text { ground in spring because there was not much manual management in the past. I } \\
\text { would dig potherbs with a small shovel and a basket, which were a delicacy at home. } \\
\text { Now that the land is managed, the mowing reduces potherbs, and some areas do not } \\
\text { let you in. } \\
\text { At that time, many residents went there to gather firewood, hunt, and pick fruit. } \\
\text { Now they have lost many things they could do in the forest. }\end{array}$ \\
\hline & & $\begin{array}{l}\text { A good sense of } \\
\text { beauty and } \\
\text { continuity }\end{array}$ & $\begin{array}{l}\text { - The mountains used to be undulating one after another. But now that artificial } \\
\text { scenery is there, the continuity is destroyed, the green continuity is reduced, and } \\
\text { artificial objects block the past scenery. }\end{array}$ \\
\hline & \multirow[t]{2}{*}{ Current } & $\begin{array}{l}\text { Artificial repairs } \\
\text { and an orderly } \\
\text { environment }\end{array}$ & $\begin{array}{l}\text { - How beautiful the park is now. There are artificially planted flowers, flat pavements, } \\
\text { and completed facilities. It is more conducive to the lifestyle of modern people. Now } \\
\text { there are many functions, for example, squares, parking, etc. } \\
\text { The current green belt is also very beautiful. The lawn is very clean and tidy. But I } \\
\text { also like the completed facilities of the current scenic spots. There are parking spaces } \\
\text { and a tourist service center, etc. }\end{array}$ \\
\hline & & $\begin{array}{l}\text { Environment } \\
\text { experience }\end{array}$ & $\begin{array}{l}\text { - When there is s nothing to do now, I go to the oxygen bar to breathe fresh air and see } \\
\text { the scenery. }\end{array}$ \\
\hline \multirow{4}{*}{$\begin{array}{l}\text { Bare } \\
\text { land }\end{array}$} & \multirow{3}{*}{ Past } & Less pollution & $\begin{array}{l}\text { - From my point of view, I preferred to preserve it as green space because green space } \\
\text { could eliminate harmful gases such as carbon dioxide. The establishment of such a } \\
\text { residential area would inevitably bring about mechanized pollution and noise. } \\
\text { Now the area has more buildings and more people. During the morning and } \\
\text { evening rush hours, there are cars, traffic jams, and noise. There is no sense of } \\
\text { village ease. }\end{array}$ \\
\hline & & Skyline flat & $\begin{array}{l}\text { - I liked the past environment. Although it was said to be a wasteland with no control } \\
\text { and weeds, it had a broad vision. } \\
\text { The past environment was better. Because the field of vision was widened and full } \\
\text { of green, the hills and slopes were all green when I looked in the distance. }\end{array}$ \\
\hline & & $\begin{array}{l}\text { Naturalness } \\
\text { highly }\end{array}$ & $\begin{array}{l}\text { - Before there were many small animals here, such as wild rabbits and pheasants. } \\
\text { - The people caught them to eat at that time. } \\
\text { wild animals on the mountains, and there were wild animals such as wild boars } \\
\text { and pheasants. }\end{array}$ \\
\hline & Current & $\begin{array}{l}\text { Environment } \\
\text { management }\end{array}$ & $\begin{array}{l}\text { - I like the current environment. It is more modern, and the surrounding facilities are } \\
\text { more complete, and have planned hospitals, schools, supermarkets, etc. In the past, } \\
\text { it was challenging to buy something, and the transportation was not convenient. } \\
\text { However, the current environment is more modern and beautiful, clean, with } \\
\text { buildings of different styles. }\end{array}$ \\
\hline
\end{tabular}




\begin{tabular}{|c|c|c|c|}
\hline $\begin{array}{l}\text { Land } \\
\text { Use }\end{array}$ & Stage & $\begin{array}{c}\text { Original } \\
\text { Encoding }\end{array}$ & The Key Interviewee Statements \\
\hline \multirow{5}{*}{$\begin{array}{l}\text { Mixed } \\
\text { land }\end{array}$} & \multirow{3}{*}{ Past } & $\begin{array}{l}\text { Naturalness } \\
\text { highly }\end{array}$ & $\begin{array}{l}\text { - In the past, the environment was good, and there were few people, and the air } \\
\text { quality was also good. There were not so many people and cars, and it was } \\
\text { comfortable. } \\
\text { The environment used to be good. The vegetation was lush, the crops were growing } \\
\text { well, and the grass on the mountain was also high, but now they are gone. }\end{array}$ \\
\hline & & $\begin{array}{l}\text { Better } \\
\text { accessibility }\end{array}$ & $\begin{array}{l}\text { - When I was young, I used to herd sheep and cattle freely in the mountain. At that } \\
\text { time, I was very free. Now there are basically fences, which are very unfree. } \\
\text { In the past, the environment was good, the view was comfortable, and the eyes were } \\
\text { full of green. Now I feel crowded. There are rules everywhere, and you can't } \\
\text { wander around. }\end{array}$ \\
\hline & & $\begin{array}{l}\text { Organic } \\
\text { agricultural } \\
\text { production }\end{array}$ & $\begin{array}{l}\text { - For me, although the cultivated land was expropriated, the government gave me } \\
\text { compensation, and I lived in a building. But I still found land nearby that could be } \\
\text { planted to grow some organic vegetables for my family. There are too many } \\
\text { vegetable fertilizers in the market. } \\
\text { In the past, there were also some pheasants in the fields. Basically, the vegetables } \\
\text { grown can be self-sufficient. There was no fertilizer, and you could eat with safety. } \\
\text { Nowadays, there is more fertilization of vegetables, and I feel unsafe. }\end{array}$ \\
\hline & \multirow[t]{2}{*}{ Current } & $\begin{array}{l}\text { Enhance } \\
\text { environment } \\
\text { experience }\end{array}$ & $\begin{array}{l}\text { - The natural environment was built into a scenic spot, which is more conducive for } \\
\text { people who have lived in the city for a long time to relax, release inner anxiety, and } \\
\text { work pressure, etc. So, I think it was better to change it like this. } \\
\text { Such a scenic leisure spot could solve my employment problem. I can come out here } \\
\text { to do odd jobs. In the environment before, there was no place for employment. }\end{array}$ \\
\hline & & $\begin{array}{l}\text { Environment } \\
\text { management }\end{array}$ & $\begin{array}{l}\text { - The environment is still good now. The scenic area has been built, and many trees, } \\
\text { lawns, and flowers have been planted, which is also very good. } \\
\text { - The roads here are very good now. There are various plants and flowers planted on } \\
\text { both sides of the road, which are very beautiful. }\end{array}$ \\
\hline \multirow{6}{*}{$\begin{array}{l}\text { Const- } \\
\text { ruction } \\
\text { land }\end{array}$} & \multirow{4}{*}{ Past } & Natural Beauty & $\begin{array}{l}\text { - Although the environment in the past was all tattered, it was good at that time. The } \\
\text { land was a mixture of crops and trees. You see, these are gone, and the air is not as } \\
\text { good as before. } \\
\text { The place used to be very muddy, and the bungalows in the village were very } \\
\text { dilapidated. In winter, it was very choking to burn coal for heating. In the summer } \\
\text { before, there were all the sounds of cicadas. But now they are gone, and nature in } \\
\text { the past was better. }\end{array}$ \\
\hline & & Less pollution & $\begin{array}{l}\text { - I liked the past environment because I liked the beauty of natural plants without any } \\
\text { artificiality; it had a sense of vastness. The past environment was better than the } \\
\text { current commercial district, and had fewer people and better air. } \\
\text { The artificial landscape is very beautiful, like a European-style town. But after the } \\
\text { completion of the construction, residents who live in urban areas would be shopping } \\
\text { on holidays, and there would be traffic jams, and the sound of car horns was } \\
\text { very harsh. }\end{array}$ \\
\hline & & Skyline flat & $\begin{array}{l}\text { I like the original environment. When I opened my eyes before, I walked outside } \\
\text { and I saw crops in the cultivated land. The eyes were full of green, and the vision } \\
\text { was broad and comfortable. }\end{array}$ \\
\hline & & Place attachment & $\begin{array}{l}\text { - Now I live in a building. Although the living environment is better, the memory still } \\
\text { impresses me. }\end{array}$ \\
\hline & \multirow[t]{2}{*}{ Current } & $\begin{array}{l}\text { Enhance } \\
\text { environment } \\
\text { experience }\end{array}$ & $\begin{array}{l}\text { - I preferred the current environment. It was good to build a place for shopping, } \\
\text { entertainment, and leisure, which is closer to the needs of people's lives. } \\
\text { Although the environment was being destroyed, for a farmer like me, it has } \\
\text { improved my life. After building such a commercial area, my family have a place to } \\
\text { work and earn money. }\end{array}$ \\
\hline & & $\begin{array}{c}\text { Good sense of } \\
\text { beauty }\end{array}$ & t is more regular after construction, and the vision looks better. \\
\hline
\end{tabular}




\begin{tabular}{|c|c|c|c|}
\hline $\begin{array}{l}\text { Land } \\
\text { Use }\end{array}$ & Stage & $\begin{array}{l}\text { Original } \\
\text { Encoding }\end{array}$ & The Key Interviewee Statements \\
\hline \multirow{6}{*}{$\begin{array}{l}\text { Cultiva- } \\
\text { ted } \\
\text { land }\end{array}$} & \multirow{6}{*}{ Current } & Less pollution & $\begin{array}{l}\text { - The past environment was better. Because there are so many people in the area now, } \\
\text { rivers here were all polluted. }\end{array}$ \\
\hline & & $\begin{array}{l}\text { Enhance } \\
\text { environment } \\
\text { experience }\end{array}$ & $\begin{array}{l}\text { - It used to be a rural area. There were not many buildings, and there were not so } \\
\text { many cars. It was quiet. }\end{array}$ \\
\hline & & $\begin{array}{l}\text { Naturalness } \\
\text { highly }\end{array}$ & $\begin{array}{l}\text { - There is less water and water pollution now. Although the river was cleaned every } \\
\text { year and clear, the water's bottom was not clear. The bottom of the river was black } \\
\text { and green. }\end{array}$ \\
\hline & & $\begin{array}{l}\text { Organic } \\
\text { agricultural } \\
\text { production }\end{array}$ & $\begin{array}{l}\text { - There were no big changes in the cultivated land. I liked it very much. Viewing the } \\
\text { urban landscape for a long time, seeing cultivated land is a kind of relaxation, and it } \\
\text { provides food for residents. There is less cultivated land on the edge of the city. I } \\
\text { hope to keep it that way, such an agricultural landscape. }\end{array}$ \\
\hline & & Place attachment & $\begin{array}{l}\text { - Cultivated land was very green in summer, and the landscape was better. I thought } \\
\text { it was better to plant trees rather than cultivated land, and forests could change the } \\
\text { climate more. }\end{array}$ \\
\hline & & Skyline flat & $\begin{array}{l}\text { - There used to be many grasshoppers on the mountain, but now there are few } \\
\text { grasshoppers. }\end{array}$ \\
\hline
\end{tabular}

\section{References}

1. United Nations. 2014 Revision of the World Urbanization Prospects. 2014. Available online: https://www.un.org/en/ development/desa/publications/2014-revision-world-urbanization-prospects.html (accessed on 12 July 2021).

2. Ning, F.E.; Ou, S.J.; Hsu, C.Y.; Chien, Y.C. Analysis of landscape spatial pattern changes in urban fringe area: A case study of Hunhe Niaodao Area in Shenyang City. Landsc. Ecol. Eng. 2021, 17, 411-425. [CrossRef]

3. Qian, F.K.; Chi, Y.R.; Lal, R. Spatiotemporal characteristics analysis of multifunctional cultivated land: A case-study in Shenyang, Northeast China. Land Degrad. Dev. 2020, 31, 1812-1822. [CrossRef]

4. Wu, W.; Li, C.L.; Liu, M.; Hu, Y.M.; Xiu, C.L. Change of impervious surface area and its impacts on urban landscape: An example of Shenyang between 2010 and 2017. Ecosyst. Health Sustain. 2020, 6, 1767511. [CrossRef]

5. Hermes, J.; Van Berkel, D.; Burkhard, B.; Plieninger, T.; Fagerholm, N.; von Haaren, C.; Albert, C. Assessment and valuation of recreational ecosystem services of landscapes. Ecosyst. Serv. 2018, 31, 289-295. [CrossRef] [PubMed]

6. Ridding, L.E.; Redhead, J.W.; Oliver, T.H.; Schmucki, R.; McGinlay, J.; Graves, A.R.; Morris, J.; Bradbury, R.B.; King, H.; Bullock, J.M. The importance of landscape characteristics for the delivery of cultural ecosystem services. J. Environ. Manag. 2018, 206, 1145-1154. [CrossRef]

7. Plieninger, T.; Bieling, C.; Fagerholm, N.; Byg, A.; Hartel, T.; Hurley, P.; López-Santiago, C.A.; Nagabhatla, N.; Oteros-Rozas, E.; Raymond, C.M.; et al. The role of cultural ecosystem services in landscape management and planning. Curr. Opin. Environ. Sustain. 2015, 14, 28-33. [CrossRef]

8. Yang, G.; Yu, Z.; Zhang, J.; Søderkvist Kristensen, L. From preference to landscape sustainability: A bibliometric review of landscape preference research from 1968 to 2019. Ecosyst. Health Sustain. 2021, 7, 1948355. [CrossRef]

9. Ho, L.D. Landscape diversity and conservation. Sci. Dev. 2009, 439, 22-29.

10. Atik, M.; Bell, S.; Erdogan, R. Understanding Cultural Interfaces in the Landscape: A Case Study of Ancient Lycia in the Turkish Mediterranean. Landsc. Res. 2013, 38, 222-242. [CrossRef]

11. Antrop, M. Reflecting upon 25 years of landscape ecology. Landsc. Ecol. 2007, 22, 1441-1443. [CrossRef]

12. Davenport, M.A.; Anderson, D.H. Getting From Sense of Place to Place-Based Management: An Interpretive Investigation of Place Meanings and Perceptions of Landscape Change. Soc. Nat. Resour. 2005, 18, 625-641. [CrossRef]

13. Hill, D.; Daniel, T.C. Foundations for an Ecological Aesthetic: Can Information Alter Landscape Preferences? Soc. Nat. Resour. 2007, 21, 34-49. [CrossRef]

14. Stephenson, J. The Cultural Values Model: An integrated approach to values in landscapes. Landsc. Urban Plan. 2008, 84, 127-139. [CrossRef]

15. Wartmann, F.M.; Frick, J.; Kienast, F.; Hunziker, M. Factors influencing visual landscape quality perceived by the public. Results from a national survey. Landsc. Urban Plan. 2021, 208, 104024. [CrossRef]

16. Devine-Wright, P.; Batel, S. Explaining public preferences for high voltage pylon designs: An empirical study of perceived fit in a rural landscape. Land Use Policy 2013, 31, 640-649. [CrossRef]

17. Luo, T. Potential of small town residents' participation in local urbanization process: A case study on the northern region of Fujian Province. City Plann. Rev. 2016, 40, 94-100. 
18. Gobster, P.H.; Nassauer, J.I.; Daniel, T.C.; Fry, G. The shared landscape: What does aesthetics have to do with ecology? Landsc. Ecol. 2007, 22, 959-972. [CrossRef]

19. Zube, E.H. Themes in Landscape Assessment Theory. Landsc. J. 1984, 3, 104-110. [CrossRef]

20. Dakin, S. There's more to landscape than meets the eye: Towards inclusive landscape assessment in resource and environmental management. Can. Geogr.-Geogr. Can. 2003, 47, 185-200. [CrossRef]

21. Vouligny, É.; Domon, G.; Ruiz, J. An assessment of ordinary landscapes by an expert and by its residents: Landscape values in areas of intensive agricultural use. Land Use Policy 2009, 26, 890-900. [CrossRef]

22. Seamon, D. The phenomenological contribution to environmental psychology. J. Environ. Psychol. 1982, 2, 119-140. [CrossRef]

23. Chen, P.J. Comparing the Landscape Evaluation Results between Experiential Paradigm and Cognitive Paradigm in Sun Moon Lake National Scenic Area. Master's Thesis, National Chung Hsing University, Taichung, Taiwan, 2012.

24. Loder, A. 'There's a meadow outside my workplace': A phenomenological exploration of aesthetics and green roofs in Chicago and Toronto. Landsc. Urban Plan. 2014, 126, 94-106. [CrossRef]

25. Liang, W.H. On the Theory and Method of Landscape Narration. China Sci. Technol. Panor. Mag. 2011, 1, 347-348. [CrossRef]

26. Verbrugge, L.; van den Born, R. The role of place attachment in public perceptions of a re-landscaping intervention in the river Waal (The Netherlands). Landsc. Urban Plan. 2018, 177, 241-250. [CrossRef]

27. Burley, D.; Jenkins, P.; Laska, S.; Davis, T. Place Attachment and Environmental Change in Coastal Louisiana. Organ. Environ. 2007, 20, 347-366. [CrossRef]

28. Kao, Y.Y.; Li, Y.H. Constructing Landscape Experience Model of Tourism Destination: A Case of Penghu Islands. J. Outdoor Recreat. Study 2017, 30, 63-90. [CrossRef]

29. Soliva, R.; Hunziker, M. Beyond the visual dimension: Using ideal type narratives to analyse people's assessments of landscape scenarios. Land Use Policy 2009, 26, 284-294. [CrossRef]

30. Zoderer, B.M.; Tasser, E.; Carver, S.; Tappeiner, U. An integrated method for the mapping of landscape preferences at the regional scale. Ecol. Indic. 2019, 106, 105430. [CrossRef]

31. Appleton, J. The Experience of Landscape; Wiley: New York, NY, USA, 1996.

32. Wilson, E.O. Biophilia; Harvard University Press: Cambridge, MA, USA, 1984.

33. Kaplan, R.; Kaplan, S. The Experience of Nature: A Psychological Perspective; Cambrige University Press: New York, NY, USA, 1989.

34. Tveit, M.; Ode, A.; Fry, G. Key concepts in a framework for analysing visual landscape character. Landsc. Res. 2006, 31, 229-255. [CrossRef]

35. Hunter, M.R.; Askarinejad, A. Designer's approach for scene selection in tests of preference and restoration along a continuum of natural to manmade environments. Front. Psychol. 2015, 6, 1228. [CrossRef]

36. Howley, P. Landscape aesthetics: Assessing the general publics' preferences towards rural landscapes. Ecol. Econ. 2011, 72, 161-169. [CrossRef]

37. Biswas, M.; Banerji, S.; Mitra, D. Land-use-land-cover change detection and application of Markov model: A case study of Eastern part of Kolkata. Environ. Dev. Sustain. 2020, 22, 4341-4360. [CrossRef]

38. Xia, H.; Ge, S.D.; Zhang, X.Y.; Kim, G.; Lei, Y.K.; Liu, Y. Spatiotemporal Dynamics of Green Infrastructure in an Agricultural Peri-Urban Area: A Case Study of Baisha District in Zhengzhou, China. Land 2021, 10, 801. [CrossRef]

39. Goodarzi, M.; Haghtalab, N.; Saeedi, I.; Moore, N.J. Structural and functional improvement of urban fringe areas: Toward achieving sustainable built-natural environment interactions. Environ. Dev. Sustain. 2020, 22, 6727-6754. [CrossRef]

40. Wang, Y.; Han, Y.L.; Pu, L.J.; Jiang, B.; Yuan, S.F.; Xu, Y. A Novel Model for Detecting Urban Fringe and Its Expanding Patterns: An Application in Harbin City, China. Land 2021, 10, 876. [CrossRef]

41. Peng, J.; Liu, Q.; Blaschke, T.; Zhang, Z.; Liu, Y.; Hu, Y.; Wang, M.; Xu, Z.; Wu, J. Integrating land development size, pattern, and density to identify urban-rural fringe in a metropolitan region. Landsc. Ecol. 2020, 35, 2045-2059. [CrossRef]

42. Hunziker, M. The spontaneous reafforestation in abandoned agricultural lands:perception and aesthetic assessment by locals and tourists. Landsc. Urban Plan. 1995, 31, 399-410. [CrossRef]

43. Home, R.; Bauer, N.; Hunziker, M. Cultural and Biological Determinants in the Evaluation of Urban Green Spaces. Environ. Behav. 2009, 42, 494-523. [CrossRef]

44. Bazrafshan, M.; Tabrizi, A.M.; Bauer, N.; Kienast, F. Place attachment through interaction with urban parks: A cross-cultural study. Urban For. Urban Green. 2021, 61, 127103. [CrossRef]

45. Hsieh, H.F.; Shannon, S.E. Three Approaches to Qualitative Content Analysis. Qual. Health Res. 2005, 15, 1277-1288. [CrossRef]

46. Mayring, P. Qualitative Content Analysis. Qual. Soc. Res. 2000, 1, 159-176. [CrossRef]

47. Meneghello, S. The tourism-landscape nexus: Assessment and insights from a bibliographic analysis. Land 2021, $10,417$. [CrossRef]

48. Che, T.; Li, C.; Luo, Y.J. Changes in landscape pattern of built-up land and its driving factors during urban sprawl. ACta Ecol. Sin. 2020, 40, 3283-3294. [CrossRef]

49. He, L.Z.; Chun, Y.C.; Chen, J.Z. Quantification of Perceived Naturalness Using Scene Gist Algorithm. J. Landsc. 2012, $18,23-38$.

50. Hull, R.B.; Robertson, D.P.; Kendra, A. Public understandings of nature: A case study of local knowledge about "natural" forest conditions. Soc. Nat. Resour. 2001, 14, 325-340. [CrossRef]

51. Landscape Institute; Institute of Environmental Management Assessment. Guidelines for Landscape and Visual Impact Assessment; Routledge: Abingdon, UK, 2013. 
52. Grahn, P.; Stigsdotter, U.K. The relation between perceived sensory dimensions of urban green space and stress restoration. Landsc. Urban Plan. 2010, 94, 264-275. [CrossRef]

53. Clay, G.R.; Smidt, R.K. Assessing the validity and reliability of descriptor variables used in scenic highway analysis. Landsc. Urban Plan. 2004, 66, 239-255. [CrossRef]

54. Hanyu, K. Visual properties and affective appraisals in residential areas in daylight. J. Environ. Psychol. 2000, 20, 273-284 [CrossRef]

55. Tahat, M.M.; Alananbeh, K.M.; Othman, Y.A.; Leskovar, D.I. Soil Health and Sustainable Agriculture. Sustainability 2020, $12,4859$. [CrossRef]

56. Ives, C.D.; Kendal, D. Values and attitudes of the urban public towards peri-urban agricultural land. Land Use Policy 2013, 34 80-90. [CrossRef]

57. Dalvi, M.Q.; Martin, K.M. The measurement of accessibility: Some preliminary results. Transportation 1976, 5, 17-42. [CrossRef]

58. Song, S.F. Some tests of alternative accessibility measures: A population density approach. Land Econ. 1996, 72, 474-482. [CrossRef]

59. Miller, H.J. Modeling accessibility using space-time prism concepts within geographiacl information-systems. Int. J. Geogr. Inf. Syst. 1991, 5, 287-301. [CrossRef]

60. Cao, S.X.; Sun, J.Y. Antecedents and Consequences of Place Attachment. J. Geogr. Sci. 2009, 55, 43-63. [CrossRef]

61. Nassauer, J.I. Cultural sustainability: Aligning aesthetics and ecology. In Placing Nature: Culture and Landscape Ecology; Nassauer, J.I., Ed.; Island Press: Washington, DC, USA, 1997; pp. 67-83.

62. van-Mansvelt, J.D.; Kuiper, J. Criteria for the humanity realm: Psychology and physiognomy and cultural heritage. Checkl. Sustain. Landsc. Manag. 1999, 116-134.

63. Ying, L.; Niu, W. Evaluation of Resident Living Convenience in the Main Urban Area of Wuhan Based on POI Data. Territ. Nat. Resour. Study 2020, 3, 14-17.

64. Altman, I.; Low, S.M. Place Attachment; Plenum Publishing Corporatiom: New York, NY, USA, 1992.

65. Raymond, C.M.; Brown, G.; Weber, D. The measurement of place attachment Personal, community, and environmental connections. J. Environ. Psychol. 2010, 30, 422-434. [CrossRef]

66. Gobster, P.H. An Ecological Aesthetic for Forest Landscape Management. Landsc. J. 1999, 18, 54-64. [CrossRef]

67. Bell, S. Landscape: Pattern, Perception, and Process; E \& FN Spon: London, UK, 1999.

68. Grammatikopoulou, I.; Pouta, E.; Salmiovirta, M.; Soini, K. Heterogeneous preferences for agricultural landscape improvements in southern Finland. Landsc. Urban Plan. 2012, 107, 181-191. [CrossRef]

69. Jacobs, M.H. The Production of Mindscapes: A Comprehensive Theory of Landscape Experience. Doctor Dissertation, Wageningen University, Wageningen, The Netherlands, 2006.

70. Berto, R. The role of nature in coping with psycho-physiological stress: A literature review on restorativeness. Behav. Sci. 2014, 4, 394-409. [CrossRef]

71. Korpela, K.M.; Hartig, T.; Kaiser, F.G.; Fuhrer, U. Restorative Experience and Self-Regulation in Favorite Places. Environ. Behav. 2001, 33, 572-589. [CrossRef]

72. van den Born, R.J.G.; Verbrugge, L.N.H.; Ganzevoort, W. Assessing stakeholder perceptions of landscape and place in the context of a major river intervention: A call for their inclusion in adaptive management. Water Policy 2019, 22, 19-36. [CrossRef]

73. Năstase, I.I.; Pătru-Stupariu, I.; Kienast, F. Landscape Preferences and Distance Decay Analysis for Mapping the Recreational Potential of an Urban Area. Sustainability 2019, 11, 3620. [CrossRef]

74. Maas, J.; Verheij, R.A.; Groenewegen, P.P.; de Vries, S.; Spreeuwenberg, P. Green space, urbanity, and health: How strong is the relation? J. Epidemiol. Community Health 2006, 60, 587. [CrossRef] [PubMed]

75. Lee, A.C.K.; Maheswaran, R. The health benefits of urban green spaces: A review of the evidence. J. Public Health 2011, 33, 212-222. [CrossRef] [PubMed]

76. Japelj, A.; Mavsar, R.; Hodges, D.; Kovač, M.; Juvančič, L. Latent preferences of residents regarding an urban forest recreation setting in Ljubljana, Slovenia. Forest Policy Econ. 2016, 71, 71-79. [CrossRef]

77. Polat, A.T.; Akay, A. Relationships between the visual preferences of urban recreation area users and various landscape design elements. Urban For. Urban Green. 2015, 14, 573-582. [CrossRef]

78. Hami, A.; Tarashkar, M. Assessment of women's familiarity perceptions and preferences in terms of plants origins in the urban parks of Tabriz, Iran. Urban For. Urban Green. 2018, 32, 168-176. [CrossRef] 